\title{
Green Road Transportation Using Biodiesel and Electric Mobility in Indonesia: A Benchmark Analysis of GHG Referring to Japan
}

\author{
Nugroho Adi Sasongko ${ }^{1,2)}$, Ryozo Noguchi*3), Sichao Kan ${ }^{4)}$, \\ Yoshiaki Shibata $^{4)}$ and Kaoru Yamaguchi ${ }^{4)}$ \\ 1) Graduate School of Life and Environmental Sciences, University of Tsukuba, \\ 1-1-1 Tennodai, Tsukuba, Ibaraki 305-8572, Japan \\ 2) The Agency of Assessment and Application of Technology (BPPT), \\ Jl. M.H. Thamrin No. 8, Jakarta 10340, Indonesia \\ 3) Faculty of Life and Environmental Sciences, University of Tsukuba, \\ 1-1-1 Tennodai, Tsukuba, Ibaraki 305-8572, Japan \\ 4) The Institute of Energy Economics Japan (IEEJ), Inui Bldg. Kachidoki, \\ 10th, 11th Floor, 1-13-1, Kachidoki, Chuo, Tokyo 104-0054, Japan
}

\begin{abstract}
This research evaluated the benefit of utilization of biofuel for internal combustion engine (ICE) vehicles and electric vehicles (EVs) in terms of environmental benefit over GHG emission reduction in Indonesia and Japan. To support the research, the forecasted GHG emission from these mobility alternatives (rather than fossil fuel internal combustion engine) within the time frame between 2015 and 2030 was reported and analysed. The life cycle assessment (LCA) of palm oilbased biodiesel production, ICE vehicles, EVs and lithium battery production were analysed by using SIMAPRO ${ }^{\circledR}$. The results showed that Japan has a better emission reduction strategy than Indonesia. Lower emission factor from power sector provides more advantage to promote EVs in Japan and expected better than other alternatives in current situation and future. On the other hand, for Indonesia, both biofuel-ICE and EVs utilization could not offer high positive impact to promote green mobility. Biofuel is insufficient to achieve emission reduction in Indonesia for transportation sector, only less than $8.0 \%$ target for transportation in 2020 and worsening of emission factor from Indonesia power generation for current situation and future. Emission mitigation strategy of the road transportation in Indonesia requisites a clearer direction, especially for future targeted biofuel crops and cleaner electricity sources.
\end{abstract}

\section{Keywords}

biofuel, electric vehicles, emission factor, green mobility, GHG emission mitigation

\section{Introduction}

The demand for automobile fuels is seen rapid growth as car-ownership in Indonesia has increased faster than Japan, which tends to persist in the future. As part of national policy, green transportation strategy is essential to be identified with

* Corresponding Author

E-mail: noguchi.ryozo.gm@u.tsukuba.ac.jp regard to the future development roadmap. In short until medium terms seems that Indonesia and Japan have different strategies for green mobility. In Indonesia, automotive technology is still relying on internal combustion engine (ICE) development. Meanwhile, Japan already progressed enough with hybrid and electric vehicles (H/EVs) technology market. The condition is even more interesting to compare, considering that both countries are working hard to reduce emissions from the transport sector. Indonesia offered to introduce and utilize bio- 
fuel and gas fuel such as compressed natural gas (CNG) and liquefied gas for vehicle (LGV) to replace gasoline and diesel fuel in order to promote greenhouse gas (GHG) emission reduction. On the other hand, Japan got more interests on EVs, supported by a cleaner electricity supply from new and renewable energy sources.

Investigation of alternative mobility, energy sources, and efficient technology utilization become major concerns to GHG emissions and energy consumption for Indonesia and Japan. The transportation sector accounted for $76 \%$ of total Indonesia petroleum consumption in 2015 (Sugiyono et al. 2016). Based on data from The National Development Planning Agency (2016), land transportation contributed to $90.7 \%$ of total $\mathrm{CO}_{2}$ emission from overall transport sector, with air and maritime contributed $2.4 \%$ and $6.9 \%$ respectively. In Indonesia, about $98 \%$ of total energy consumption in the transportation sector is provided by petroleum products. In 2015, the largest sources of GHG emissions were passenger cars of $43.1 \%$ from total transportation sectors (Wright and Rahmanulloh 2017). Recently, automobiles technology improvement are well developed especially related to ergonomic. The current passenger car is very reliable, comfortable, relatively safe and environmentally friendly due to lower tailpipe emission, popularly known as a green car. However, there are some challenges and opportunity that can be improved, such as fuel efficiency, the ability to use renewables and reducing the total tail pipe emission.

In current automobile market situation both for Japan and Indonesia, the economic driving forces encourage the efficiency of most vehicles to be improved. Japan's automakers promote numbers of innovation for future fuel economy standard with various sophisticated technologies for the next generation vehicles. Based on 2015 fuel economy data, Japanese gasoline powered passenger cars standard was $20.1 \mathrm{~km} \cdot \mathrm{L}^{-1}$ or equal to $4.9 \mathrm{~L}$ of fuel for $100 \mathrm{~km}$ travel distance. Meanwhile for $\mathrm{CO}_{2}$ target in 2020 is $105 \mathrm{gCO}_{2} \mathrm{eq} \cdot \mathrm{km}^{-1}$ or equal to $4.5 \mathrm{~L}$ of fuel per $100 \mathrm{~km}$ travel distance (FIA Foundation 2016). " $\mathrm{gCO}_{2} \mathrm{eq}$ " represents quantification as the global warming potential unit of gram car- bon dioxide equivalent. On the other side, the passenger cars in Indonesia has the fuel consumption average 8.31 and $9.37 \mathrm{~L} \cdot 100 \mathrm{~km}^{-1}$ for diesel and gasoline engines, respectively based on baseline data in 2013 (Safrudin 2016a). Table 1 shows a general comparison between Indonesia and Japan related to fuel economy standard and future target and also the current condition of power generation.

Fig. 1 shows the rapid increasing of selected power trains in Indonesia and Japan between 1990 and 2016. Recent national data stated that the total number of registered vehicles in Indonesia was doubled from approximately 7 million to 14 million units between 2007 and 2016 (Kawakami 2016, APERC 2016a, 2016b, Safrudin et al. 2016b). Based on a recent report from GAIKINDO (2017), the automobile brands in Indonesia are dominated by Japanese products with $97.14 \%$ and $99.00 \%$ of domestic production and market share in the previous year, respectively. The rise in the urban population and driving in Indonesia increases the GHG and air pollution due to transportation and worsening the traffic congestion.

Fig. 2 indicates that the fuel consumption in Japan has been decreasing since 2000, this occurred mainly due to Japanese government promoted public transportation, especially electric train. The Japanese government also provides a national subsidy for consumers who purchase EVs, plug-in hybrid electric vehicle (PHEV), fuel-cell electric vehicle (FCEV), clean diesel vehicles (CDV); subsidy to develop EVs supply equipment and also R\&D of batteries. The target for H/EVs share is $20-30 \%$ by 2020 and $30-40 \%$ by 2030 of new passenger vehicle sale; PHEV $15-20 \%$ by 2020 and $20-30 \%$ by 2030 ; BEV, the market share will be $15-20 \%$ by 2020 and $20-30 \%$ by 2030 ; FCEV is targeted $1 \%$ by 2020 and $3 \%$ by 2030 ; and clean diesel is estimated 5\% by 2020 (IEA 2016a, 2016b).

Meanwhile, fuel consumption in Indonesia is increasing very rapidly. Based on a report from IEA (April 2016), the average annual growth rate of total fuel demand for transportation between 2000 and 2013 in Indonesia is $2.2 \%$, in opposite for Japan is $-1.8 \%$, over the same period. The government of Japan

Table 1 Comparison of current condition between Indonesia and Japan related to road transportation and energy development

\begin{tabular}{|c|c|c|c|}
\hline Description & Indonesia & Japan & References \\
\hline Fuel economy target by actual condition & & & IEEJ (2016) \\
\hline $2015\left[\mathrm{gCO}_{2} \mathrm{eq} \cdot \mathrm{km}^{-1}\right]$ & 130 & 125 & WEC (2016) \\
\hline $2020\left[\mathrm{gCO}_{2} \mathrm{eq} \cdot \mathrm{km}^{-1}\right]$ & 125 & 105 & JAMA (2016) \\
\hline Fuel standard for New Light-Duty Vehicles 2016 & Euro 2 & $\mathrm{JC} 08$ & \\
\hline Number vehicles in 2016 [unit] & $14,331,900$ & $61,668,713$ & $\begin{array}{c}\text { Indonesia Police Office (2017) } \\
\text { JAMA (2017) }\end{array}$ \\
\hline 2016 Grid emission factor $\left[\mathrm{gCO}_{2} \mathrm{eq} \cdot \mathrm{kWh}^{-1}\right]$ & 757.5 & 365.0 & IGES (2017) \\
\hline
\end{tabular}




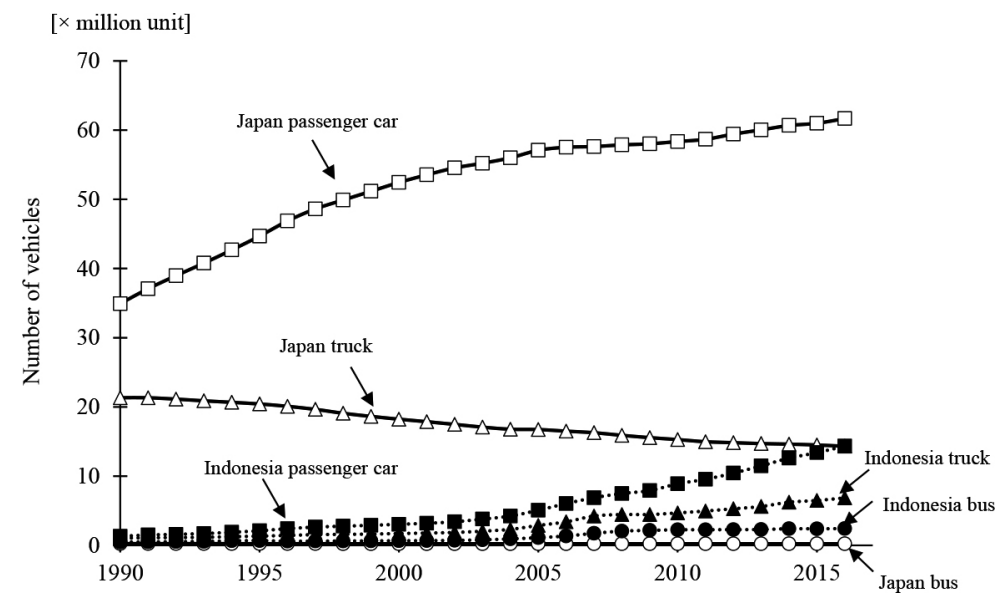

Fig. 1 Number of selected vehicles in Japan and Indonesia (Indonesian Police Office 2016, Japan Automobile Manufacturers Association Inc. 2016)

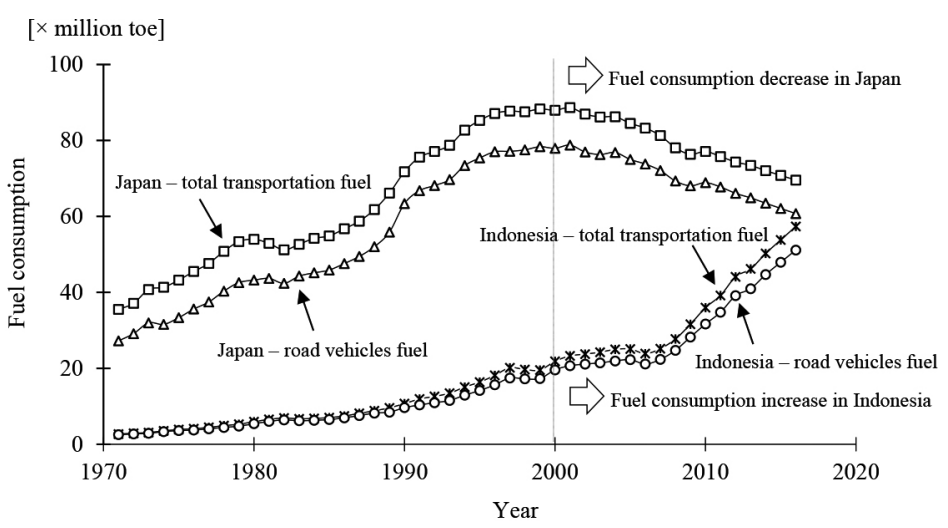

toe: ton of oil equivalent

Fig. 2 Comparison of fuel consumption in Japan and Indonesia from 1970-2015 in transportation sector (IEA 2016b)

estimates that fuel demands will continue to decrease, mainly because of declining in the number of automobiles as a result of the decline of Japan's population and improving fuel efficiency and penetration of fossil fuel-saving vehicles, such as hybrid cars. In 2012, there were about 1.5 million of the next-generation vehicles in Japan by using alternative energy such as biofuel and EVs (APERC 2016a, 2016b).

In 2016, Indonesia's transportation sector consumed about 27 million $\mathrm{kL}$ diesel fossil fuel and estimated keep increase (Wright and Rahmanulloh 2017). As an effort to promote fuel efficient on urban driving, the government launched a LowCost Green Car (LCGC) program. However, it creates a new problem in the urban area, causing the massive increase in the number of vehicles run on the highway and fuel consumption (Junoasmono 2015). As a result, this program further stimulates rapid fuel consumption in Indonesia. One of the best option to encounter this issue is by developing the next generation vehicles with alternative energy sources which provide an effective means of reducing GHG emissions. Among the various options, ICE run on biodiesel and EVs were often measured as better options than ICE run on diesel fossil fuel regarding GHG emission mitigation. Some references mentioned that EVs were often considered as better options in terms of GHG emission and energy consumption compared to conventional ICE (Onat et al. 2015).

This study examined the utilization of biofuel-based ICEs and EVs by GHG emission assessment for Japan (a pioneer on the environment strategy) and Indonesia (it is undeveloped framework). The environmental load of the input sources to the life cycle of the automobile products was properly analyzed to obtain the comprehensive analysis.

Indonesia and Japan have been selected for this study since both countries have a different situation, Indonesia has a large source of biofuel from palm oil meanwhile Japan has a clean electricity supply. Moreover, as another the substantial point is that the Japanese car automobiles are dominated in Indonesia and understanding the green mobility policy from the principal country is very necessary for adopting the best strategy. The investigation was conducted to analyze the alternative fuel utilization of biodiesel for road transportation in Indonesia and 
compare with EVs regarding specific tail pipe carbon emissions. Based on the situations stated above, the strategic framework for green mobility in Indonesia and Japan has been analyzed and the LCA methods are necessary to be conducted to understand the best alternative automobile technologies of ICE fueled by fossil, ICE fueled by biodiesel and EVs utilized the national power grid. As Indonesia transportation sector heavily relies on petroleum and it is a major contributor to the nation's GHG emissions, the analysis is focused on current condition and future forecast of potential energy saving and GHG emission for those three mentioned options especially for Indonesia within the time frame between 2015 and 2030.

\section{Methodology}

\section{Life Cycle Assessment (LCA) method}

LCA was used to quantify the environmental impacts of products or processes throughout the production, utilization and end of life phases. SIMAPRO ${ }^{\circledR}$ (PRé Consultants B.V., the Netherlands) coupled with Ecoinvent ${ }^{\circledR}$ were used to design the process and calculated complex energy and material balances, including environmental inventories. Primary data was obtained from field measurement of biofuel crops (palm oil and microalgae). Meanwhile, the available database from GREET $^{\circledR}$ for ICE, diesel fossil fuel, EVs and lithium battery production life cycle were used (Argonne National Laboratory 2017). The APEC Energy Demand and Supply Outlook (APERC 2016a) and BPPT Indonesia Energy Outlook (Sugiyono et al. 2016) were used as the initial information for LCA. The analysis also discussed the life cycle of the battery which is one of the essential parts in any vehicle types. Meanwhile, for overall life cycle assessment, two methods were used; a well to wheel method for fuel and electricity use and a cradle to grave method was considered for production of automobiles, battery, and spare-parts as shown in Fig. 3. In addition, GHG emissions and energy consumption in maintenance and end life/disposal were also included in the analysis.

\section{Scope and calculation framework}

The trend of fuel consumption in Indonesia and Japan was analyzed to forecast future condition including biofuel utilization as fuel blended (B10, B20). This research also demonstrated the impacts of battery and vehicle manufacturing over GHG emissions in the production life cycles. Further, the calculation framework of GHG emission from ICE and EVs was formulated based on a generic approach of emission control for each defined stages. Energy consumption and GHG emissions from automobile manufacturing for ICE and EVs were calculated by using LCA inventory database from SIMAPRO ${ }^{\circledR}$ and GREET $^{\circledR}$ for the Transportation Vehicle-Cycle model (Argonne
National Laboratory 2017). In this assessment, the small to medium ICE vehicles (up to 2,500 cc of engine size) were analyzed. This range of ICE size was selected based on the current trend of personal vehicles running on the road. The average national data for Indonesia was obtained from the previous study by the Ministry of Energy and Mineral Resources, Ministry of Transportation and Ministry of Environment (Safrudin 2016a, Safrudin et al. 2016b). Meanwhile, comprehensive analysis on ICE vehicles was derived from the previous studies of Kawakami (2016), and Maruyama (2012) were used for Japan's situation.

As shown in Fig. 4, this study only focuses on vehicle technology with ICE and electric motor running on fossil fuel, biofuels or electricity as the energy sources. This study did not include the economic evaluation that needs to be considered for further research, to understand the overall impact of current condition to a future scenario. Meanwhile, biodiesel $10 \%$ blended (B10) was possible to be used directly (drop-in) to current and future ICE without significant modification of engine design even though the Japan Automobile Manufacturers Association (JAMA) only recommends for up to $7 \%$ fuel blended (B7) for current ICE technology. Recently Indonesia government pushes the mandate to use of B20 despite less efficiency to boost national biofuel utilization. However, this research was not included other important sources of variability, such as actual driving patterns, another type of electric two wheelers, hybrid electric vehicle (HEV) and fuel cell electric vehicle (FCEV) in Indonesia and Japan.

\section{System design for evaluation functions}

Average ICE and EVs emission ( $\bar{E}_{I C E}$ and $\left.\bar{E}_{E V S}, \mathrm{gCO}_{2} \mathrm{eq} \cdot \mathrm{km}^{-1}\right)$ were calculated based on the historical data. In ICE, a mileage or fuel efficiency of the power train is known as an average fuel economy $(\overline{F E})$, meanwhile, it is called as EVs efficiency for EVs. It can be expressed as $\mathrm{L} \cdot \mathrm{km}^{-1}$ or $100 \mathrm{~km} \cdot \mathrm{L}^{-1}$ and $\mathrm{kWh} \cdot \mathrm{km}^{-1}$ for ICE and EVs, respectively (US Department of Energy 2017). GHG emission of the average specific fuel emission from the production of a standard fuel $\left(\overline{S F E}_{(t y p e ~ o f ~ f u e l)}, \mathrm{gCO}_{2} \mathrm{eq} \cdot \mathrm{L}^{-1}\right)$ was obtained from the production chain for a specific fuel product from wellhead (fossil fuel) or biofuel crops-farming land by considering the potential emission from total carbon intensity in each specific energy content $\left(I_{\text {carbon }}, \mathrm{gCO}_{2} \mathrm{eq} \cdot \mathrm{MJ}^{-1}\right)$ and energy density of each specific fuel $\left(\rho_{\text {energy }}, \mathrm{MJ} \cdot \mathrm{L}^{-1}\right.$ or $\left.\mathrm{MJ} \cdot \mathrm{kg}^{-1}\right)$. To calculate carbon intensity, GHG emission has to be defined from each process stages $(p)$. Meanwhile, energy density is defined as the amount of energy stored in a given system or region of space per unit volume or mass, or sometime called as specific energy with a physical unit $\mathrm{MJ} \cdot \mathrm{L}^{-1}$. The formulations are described as below:

$$
\bar{E}_{I C E(\text { engine } \leq 2500 c c)}=\overline{F E}_{(\text {engine } \leq 2,500 c c)} \times \overline{S F E}_{(\text {type of fuel })}
$$




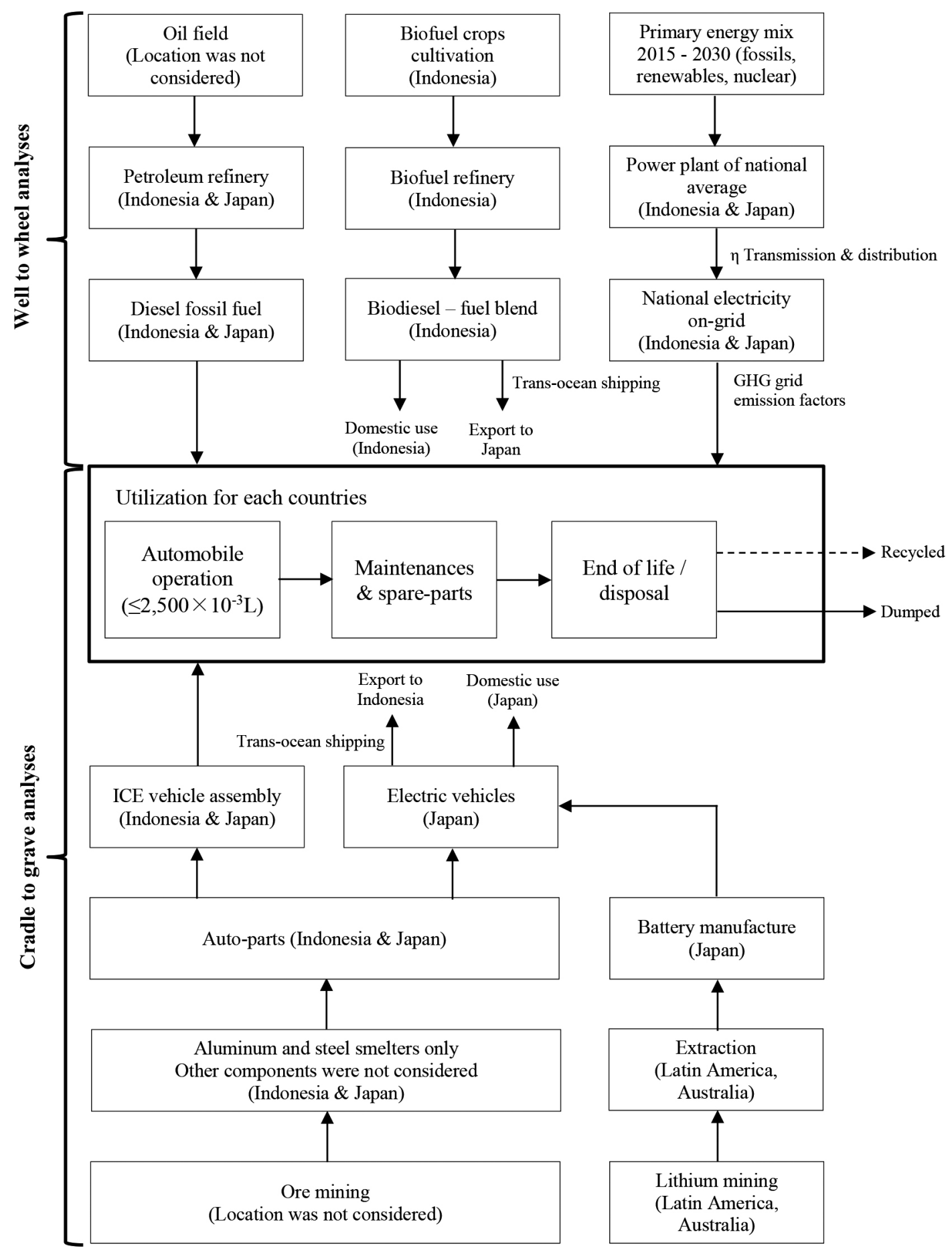

Fig. 3 Detail of boundary condition for LCA calculation

and

$$
\overline{\operatorname{SFE}}_{\text {(type of fuel) }}=I_{\text {carbon }} \times \rho_{\text {energy }}
$$

Type of standards that used in this emission calculation is limited to only Euro 2 for Indonesia and selected ASEAN countries and JC08 for Japan. Meanwhile, specific emission for biodiesel was calculated based on GREET model.

Meanwhile, since we had selected only 1 type of EVs (Nissan Leaf 2017) with a specific efficiency $\left(\eta_{E V S}\right)$, then the equation is defined as below,

$$
\begin{aligned}
& \bar{E}_{(E V S, y)}=\eta_{E V S} \times \overline{E F}_{\text {grid (country, } y)} \\
& \eta_{E V S}=\eta_{\text {battery }} \times \eta_{\text {inverter }} \times \eta_{\text {electric motor }} \times \eta_{\text {transmission }}
\end{aligned}
$$

Average mile distance EVs of $5.626 \mathrm{~km} \cdot \mathrm{kWh}^{-1}$ has been used for assumption based on Nissan LEAF performance (NISSAN 2017). Grid emission factor ( $\overline{E F}_{\text {grid }}$ (country,y), $\left.\mathrm{gCO}_{2} \mathrm{eq} \cdot \mathrm{kWh}^{-1}\right)$ was calculated from national average of emission from power 


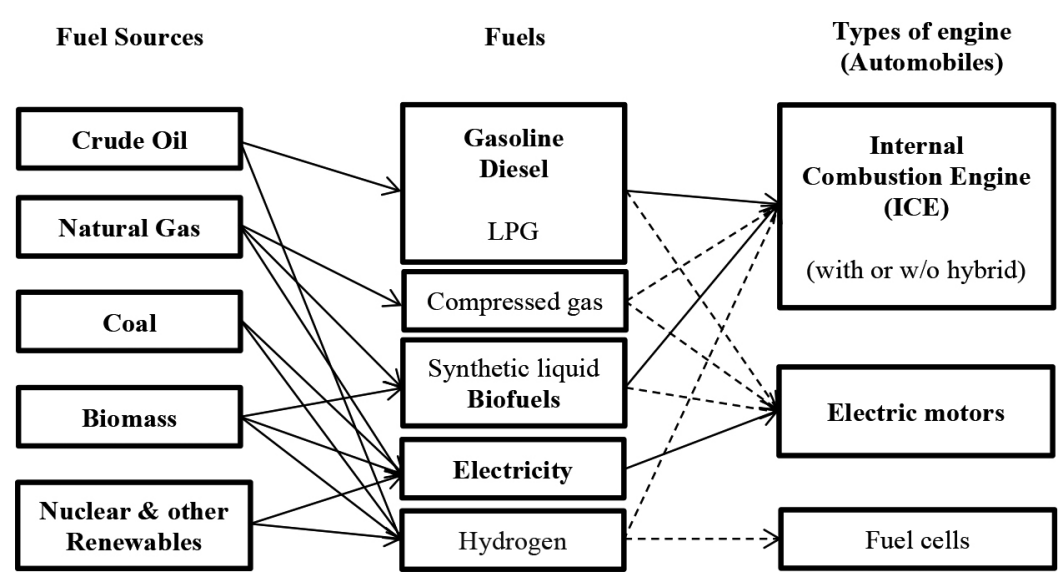

Fig. 4 Energy carriers and vehicle technologies that analyzed in this research

generation for each specific year. The simple emission factor is calculated based on the net electricity generation of each power unit and an emission factor for each power unit, as follows;

$$
\overline{E F}_{\text {grid }(\text { country }, y)}=\frac{\sum_{m} E G_{m, y} \times E F_{e l, m, y}}{\sum_{m} E G_{m, y}}
$$

where:

$\overline{E F}_{\text {grid }}$ country,$\left.y\right)=$ national average of emission from power generation for each specific year $\left[\mathrm{gCO}_{2} \mathrm{eq} \cdot \mathrm{kWh}^{-1}\right]$

$E G_{\text {grid,year }}=$ net quantity of electricity generated and delivered to the grid by power unit $\mathrm{m}$ in year y [kWh]

$E F_{\text {el,m,year }} \quad=\mathrm{CO}_{2}$ emission factor of power unit $\mathrm{m}$ in year $\mathrm{y}\left[\mathrm{gCO}_{2} \mathrm{eq} \cdot \mathrm{kWh}^{-1}\right]$

$=$ all power units serving the grid in year $y$ except low-cost/must-run power units

$y=$ The relevant year as per data vintage chosen

Meanwhile, if for a power unit $m$ data on fuel consumption and electricity generation is available, the emission factor $\left(E F_{e l, m, y}\right)$ should be determined as follows:

$$
E F_{e l, m, y}=\frac{\sum_{i} F C_{i, m, \text { year }} \times N C V_{i, y} \times E F_{C O_{2}, i, y}}{\sum_{m} E G_{m, y}}
$$

where,

$E F_{e l, m, y}=\mathrm{CO}_{2}$ emission factor of power unit $m$ in year $y$ $\left[\mathrm{gCO}_{2} \mathrm{eq} \cdot \mathrm{kWh}^{-1}\right]$

$F C_{i, m, y} \quad=$ amount of fuel type $i$ consumed by power unit $m$ in year $y$ [mass or volume unit]

$N C V_{i, y}=$ net calorific value (energy content) of fuel type $i$ in year $y$ [MJ mass ${ }^{-1}$ or volume unit]

$E F_{C_{2}, i, y}=\mathrm{CO}_{2}$ emission factor of fuel type $i$ in year $y$ [gCO${ }_{2} \mathrm{eq} \cdot \mathrm{MJ}^{-1}$ ]

$F G_{m, y} \quad=$ net quantity of electricity generated and delivered to the grid by power unit $m$ in year $y[\mathrm{kWh}]$ $m \quad=$ all power units serving the grid in year $y$ except low-cost/must-run power units

$i=$ all fuel types combusted in power unit $m$ in year $y$

$y=$ the relevant year as per the data vintage chosen

The calculation of GHG emission for both ICE and EVs included: battery, vehicle production, spare parts, maintenance, disposal and recycle. In addition, energy consumption, load, and battery efficiency were also included in EVs. Based on the latest trend, annual improvement in ICE is around 1-2\% (ERTRAC 2016) with the world fuel economy improvement targets $5.7-6.1 \%$ per annum to reach $30 \%$ efficiency increase by 2020 (WEC 2016). Meanwhile, 2.5\% per annum improvements to EVs fuel economy (Wh consumed per $\mathrm{km}$ ) was targeted in EU and Japan, and average passenger vehicle energy requirements of $0.17 \mathrm{kWh} \cdot \mathrm{km}^{-1}$ can be estimated for 2020 (WEC 2016).

\section{Emission factor from selected internal combustion engine and transportation}

In current available technology, a best in conventional diesel class has emission factor around $130 \mathrm{gCO}_{2} \mathrm{eq} \cdot \mathrm{km}^{-1}$ which by 2020 is predicted will reduce to less than $95 \mathrm{gCO}_{2} \mathrm{eq} \cdot \mathrm{km}^{-1}$ (EEA 2016). A $\mathrm{CO}_{2}$ eq emission mean values of $51 \mathrm{gCO}_{2} \mathrm{eq} \cdot \mathrm{km}^{-1}$ derived from IGES (2017) and $122 \mathrm{gCO}_{2} \mathrm{eq} \cdot \mathrm{km}^{-1}$ of fuel economy standard JC08 were used to calculate EVs and ICE vehicles mode cycle in Japan, respectively. The average emission factor for selected engine sizes is shown in Table 2. The emission factor from maritime transportation has been used to analyze the impact of commodity trading between Indonesia and Japan for biodiesel, batteries and automobile components for ICE and EVs (Table 3). These values include emission of maritime transportation for freight sea trans-oceanic tanker from Dumai Port (Riau) to Yokohama (Japan) and from Yokohama to Tanjung Priok (Jakarta). The total transportation distance is approximately 3,102 nautical miles or $5,745 \mathrm{~km}$. Additional $0.725 \mathrm{gCO}_{2} \mathrm{eq} \cdot \mathrm{MJ}^{-1}$ biodiesel from sea transport was included. The distance on the 
Table 2 Average $\mathrm{CO}_{2}$ emission factors by engine size 2016 in Japan

\begin{tabular}{lccc}
\hline \multicolumn{1}{c}{ Vehicle types } & Engine size $\left[\times 10^{-3} \mathrm{~L}\right]^{*}$ & Size & Emission $\left[\mathrm{gCO}_{2} \mathrm{eq} \cdot \mathrm{km}^{-1}\right]$ \\
\hline Petrol car & $<1,400$ & Small & 122.4 \\
& $1,400-2,000$ & Medium & 151.0 \\
& $>2,000$ & Large & 238.8 \\
Average for Petrol car & & & 170.7 \\
\hdashline Diesel car & $<1,700$ & Small & 115.2 \\
& $1,700-2,000$ & Medium & 134.7 \\
& $>2,000$ & Large & 168.9 \\
Average for Diesel car & & & 139.6 \\
\hline
\end{tabular}

Kawakami, Y. (2016); JAMA (2017)

Table 3 Average $\mathrm{CO}_{2}$ emission factors by maritime transport 2013

\begin{tabular}{lccc}
\hline \multicolumn{1}{c}{ Ships type } & Bulk Size [tons] & Emission $\left[\mathrm{gCO}_{2} \mathrm{eq} \cdot \mathrm{tkm}^{-1}\right]$ & References \\
\hline Small tanker & 844 & 20.00 & DEFRA (2016) \\
Large tanker & 18,371 & 5.00 & DEFRA (2016) \\
Deep-sea tanker & 120,000 & 5.00 & NTM (2016) \\
Trans-Oceanic tanker 1 & $\sim 120,000$ & 5.94 & Simapro 8.1.1 (2016) \\
Trans-Oceanic tanker 1 & $\sim 120,000$ & 6.13 & Simapro 8.1.1 (2016) \\
\hline
\end{tabular}

transportation routes of EVs, ICE, biofuel, and lithium were calculated.

\section{Emission factor from on-grid power sector}

Since the GHG intensity of EVs is highly dependent on the electricity source, the power generation mix for each country and the forecast of incremental electricity generation were included in the calculation. As a baseline, the 2015 average emission factor for Indonesia and Japan was calculated from on-grid power source both from fossil fuel and renewables (Fig. 5). The projection of emission factor from the power sector for both countries was based on the realistic scenario and estimated by extrapolation method of the power generation growth. The data for power generation in Indonesia was taken from Electricity Business Plan of National Electricity Company PT. PLN Persero (MEMR 2017). Business as usual (BAU) and high scenario (HS) of economic growth were simulated from Indonesia economic growth of $5.1 \%$ and $5.7 \%$ projection by Coordinating Minister for the Economy, which consider the power generation mix up to 2030. Meanwhile, 1.7\% per year was assumed for Japan economic growth until 2030 (METI 2015). Current Indonesia power plants are dominated by fossil fuel, mainly coal with approximately more than $50 \%$ share (Sugiyono et al. 2016). Following current government policy to increase electrification ratio by setting up more power plant (35GW installed capacity), which $80 \%$ was coal fired power plant type, further intensifies the grid emission factor. In addition, type of technology and efficiency of the power system also influence to the specific emission factor. Meanwhile, the power generation projection for Japan was taken from the latest energy outlook from METI (2015). Fig. 6 shows emission factors from on grid power generation in selected countries including Japan and Indonesia, calculated from IGES (2017). The emission factor from Indonesia's power sector is extremely high, approximately 2 times higher than Japan. This condition places Indonesia as the most polluted countries in Asia together with China and India. The pollution occurs during power generation was assumed as a point emission source and potential to facilitate the emission traps. If technology changes in a way to allow emission to be easily trapped, stored, or removed by any processes, use of the EVs potentially reduce GHG emission.

\section{Emission factor from energy carrier (liquid fuel and battery)}

In this study, the GHG emission of fuel products was calculated from wellhead to refinery stage by using GREET ${ }^{\circledR}$ software. The energy balances were calculated for biodiesel refineries and biofuel product transportation to blending system at fuel filling stations. The source of biofuel production was assumed 


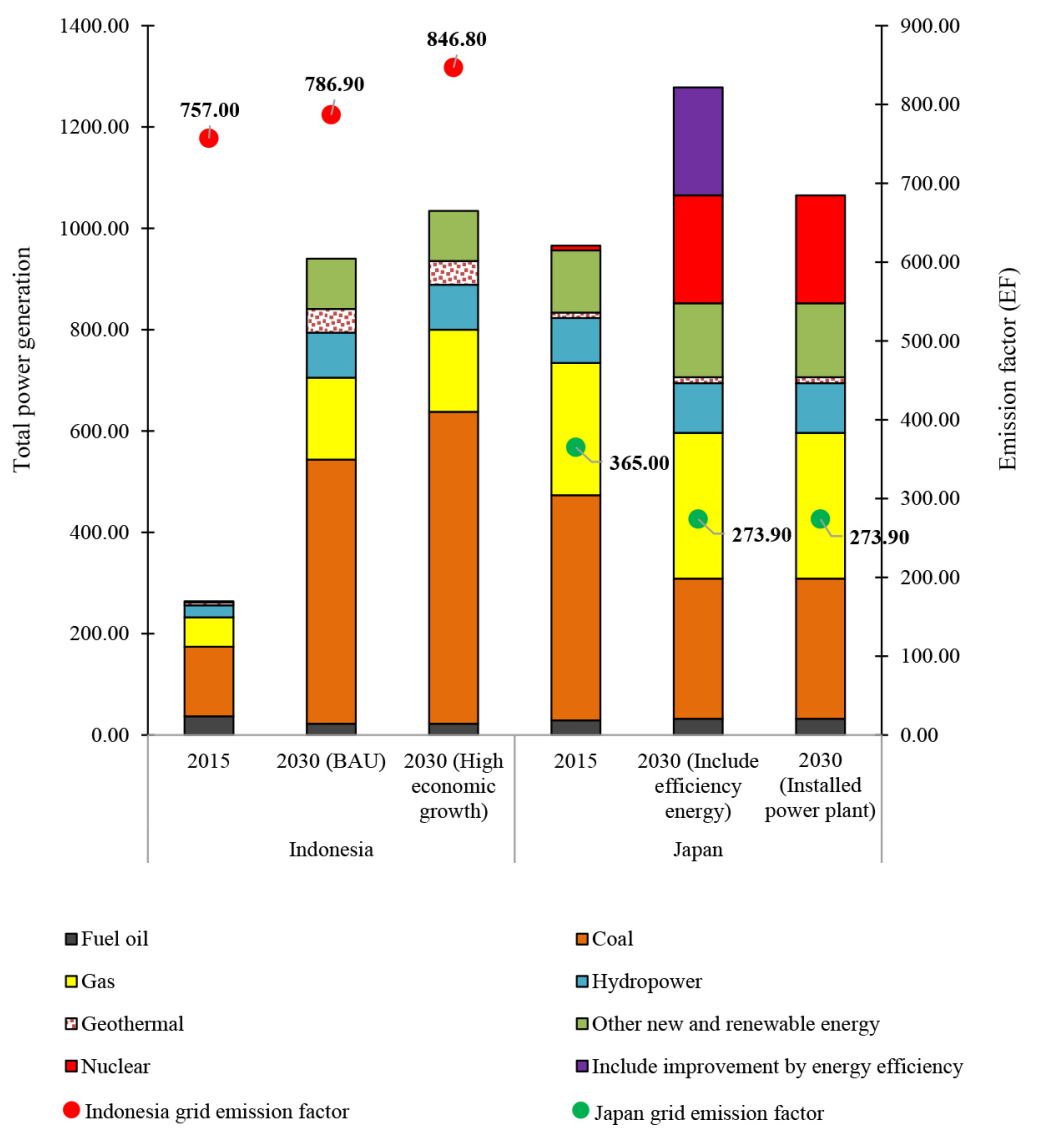

Fig. 5 Status of power generation mix in Indonesia and Japan for 2015 and final projection for 2030

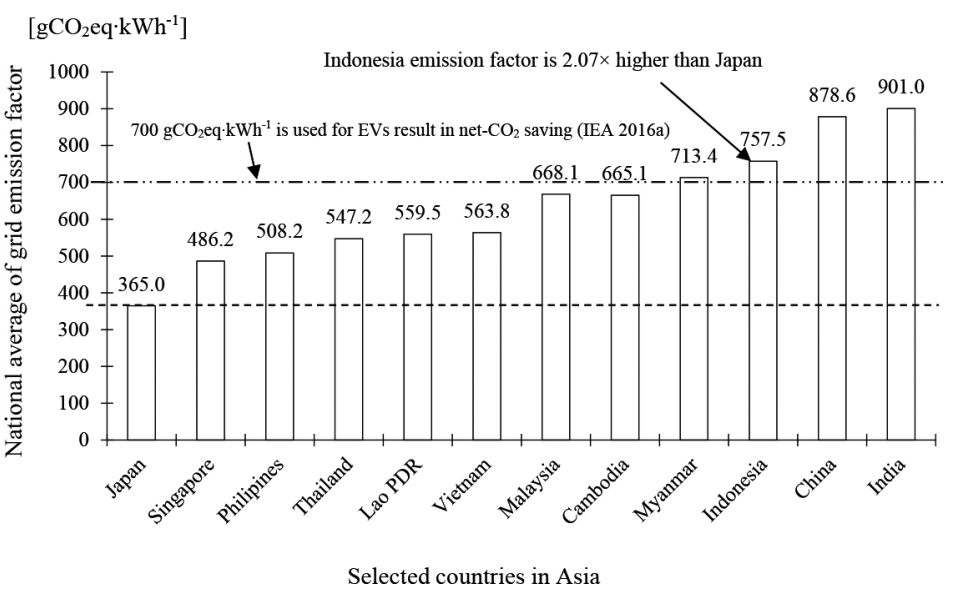

Fig. 6 Emission factor from power grid in 2016 at several countries in Asia

from Indonesia. In addition, biofuel production was allocated for domestic consumption for Indonesia. We also assumed that the domestic biofuel production in Indonesia is exceeded and a portion of Japan's biofuel demand was fulfilled by imported from Indonesia. Meanwhile, the battery life cycle products were calculated by using data as shown in Table 4 . The battery has lower energy density than liquid fuel (including biodiesel) and for present-day technology, material for battery was relatively heavy resulted in the shorter driving distance. Consequently, liquid fuels are more preferred as the energy carrier for today's automobile. Latin American countries and Australia were assumed as the primary source of the Lithium ores and the largest reserves in the world (Swiss Resource Capital AG (SRC) 2016, Perotti and Coviello 2015). The raw material of lithium 
Table 4 Battery lifetime analysis

\begin{tabular}{lcc}
\hline \multicolumn{1}{c}{ Battery lifetime analysis } & Energy $\left[\mathrm{MJ} \cdot \mathrm{km}^{-1}\right]$ & Emissions $\left[\mathrm{gCO}_{2} \mathrm{eq} \cdot \mathrm{km}^{-1}\right]$ \\
\hline BEV, battery replaced once during lifetime & 1.865 & 119.00 \\
BEV, battery partially replaced $(50 \%$ base case $)$ & 1.750 & 109.00 \\
BEV, no battery replacement & 1.635 & 101.00 \\
\hline
\end{tabular}

Simapro 8.1.1 (2016); Onat, et al. (2015); IEA (2016a)

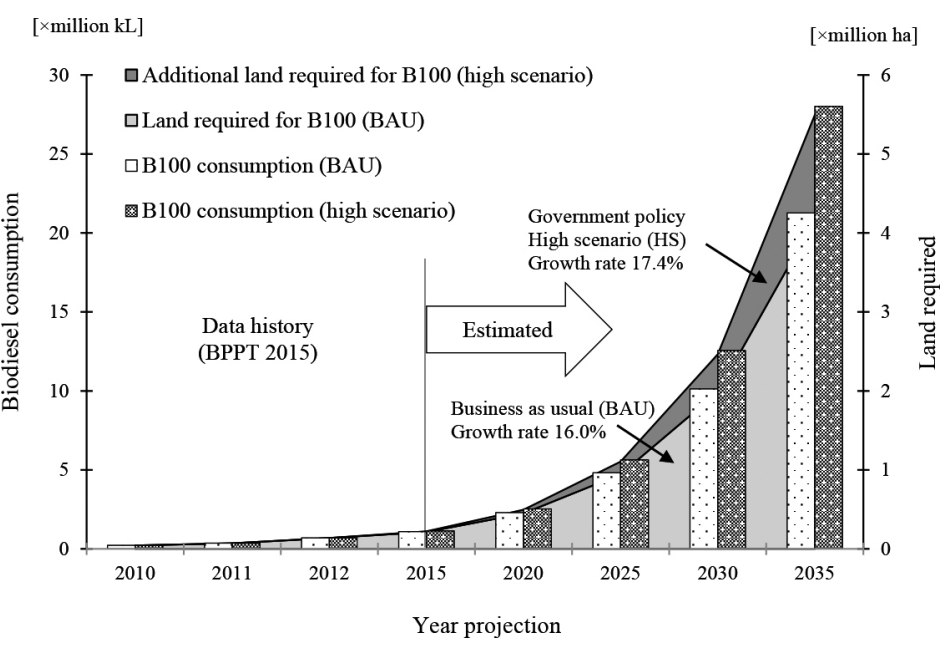

Fig. 7 Forecast of biodiesel consumption and land required in Indonesia for transportation sector

was shipped to the manufacturers in Japan before assembly into the EVs and sell to the market both in Japan and south-east Asia. The environmental impact associated with the lithium during mining activities was found very limited. Thus, it should be noted that different analysis might have a different result related to the environmental impact assessment.

\section{Results and Discussion}

\section{Biofuel utilization in Indonesia}

The drivers for nation-wide biofuel support in Indonesia mainly as an alternative from importing fossil fuel with regard to national energy security and to protect the national palm oil industries through the balancing of national and world market prices. Besides to reduce the domestic use of fossil fuel, the development of Indonesia's biofuel is also critical to alleviate unemployment and reinforce economic activity in the rural areas. However, we also consider if biofuel policies might give significant effect to edible oil supplies, decrease the crop lands and increase food prices.

Considering the positive consequences from biofuel utilization, Indonesia government stipulated a regulation of the ministry of energy and mineral resources (MEMR) No. 12/2015 about supply, utilization, and the marketing of biofuels as other fuels, to increase the biodiesel use and strongly encourage for each public fuel filling station to have a special dispenser for fuel blended of fossil diesel and biodiesel. The domestic biodiesel consumption is expected to be increased in the upcoming years (Fig. 7). By using the biodiesel demand from 2010-2015 as a baseline, biodiesel utilization potentially increases the growth rate of $16 \%$ up to $17.4 \%$ for a BAU and HS of government policy target, respectively. Therefore for road transportation, the total land required to support biodiesel crops will reach nearly 3 million ha in 2030. When the tropical forests, peatlands, and other agricultural lands that are rich in carbon converted to biofuel crop's land, large quantities of GHG might release. However, these negative issues can be minimized if abandoned fields or degraded lands are utilized for biofuel crops which could help to mitigate the climate change and lessen the chance of raising food prices as well (Fairhurst and McLaughlin 2009, Gingold et al. 2012, Smit et al. 2013). If we can anticipate the biodiesel produced from non-abandoned land, its utilization has high potential to reduce a significant amount of emission from road transportation sector. However, the automobile industry also needs to produce the advanced 'drop-in' fuels derived from various feedstocks such as microalgae or other bio-resources that do not compete with food production.

Following the Bali Action Plan from UNFCCC - COP 13, Indonesia's voluntary pledged to reduce GHG emissions by $26 \%$ on its own efforts and up to $41 \%$ with international sup- 
port, against the BAU scenario by 2020 (UNFCCC 2008). This commitment was adopted into a Presidential Decree No 61 (2011) about the national action plan on greenhouse gas emission reduction and Presidential Decree No 71 (2011) about the operation of national greenhouse gas inventory. Beyond 2020, Indonesia envisions an even bolder commitment to emission reductions. Based on the country's most recent emissions level assessment, the unconditional reduction target is $29 \%$ of BAU scenario by 2030 . However, the total target of GHG emission reduction for $26 \%$ scenario is equal to $0.767 \mathrm{GT}$ of $\mathrm{CO}_{2}$ eq. Meanwhile, for $41 \%$ scenario is equal to $2.82 \mathrm{GT}$ of $\mathrm{CO}_{2}$ eq. As shown in Fig. 8, we found that the possible GHG emission reduction by biofuel utilization in Indonesia transportation sector will only achieve up to $8.00 \%$ in 2020 . Furthermore, the $8.0 \%\left(3.04 \times 10^{-3} \mathrm{GT}\right)$ contribution to the emission reduction in the transportation sector is relatively small compared to its minimum target portion for $2020\left(3.80 \times 10^{-2}\right.$ GT) (Fig. 9). Consequently, biofuel utilization might be assumed as an alternative from a number possible measures in GHG emission reduction from transportation.

\section{Tail pipe emission forecast from diesel fossil fuel, biodiesel, and EVs utilization}

The progress of green mobility in Indonesia is very challenging due to unclear emission reduction strategies. The use of biofuels for conventional ICE offers a substantial possibility of GHG emission reduction without requires expensive batteries, long charging time and without significantly limit the driving range. Meanwhile, other alternatives, such as EVs also considered as a key technology for future sustainable mobility.

However, for current emission regulation, most of the automobile markets regulate $\mathrm{CO}_{2}$ eq footprint and fuel economy as the substantial commercial promotion values. The deployment of energy-efficient vehicles is encouraged by increasingly stringent fuel economy or tailpipe $\mathrm{CO}_{2}$ emission regulation and standards. Based on our calculation, $\mathrm{CO}_{2}$ eq emission for a conventional

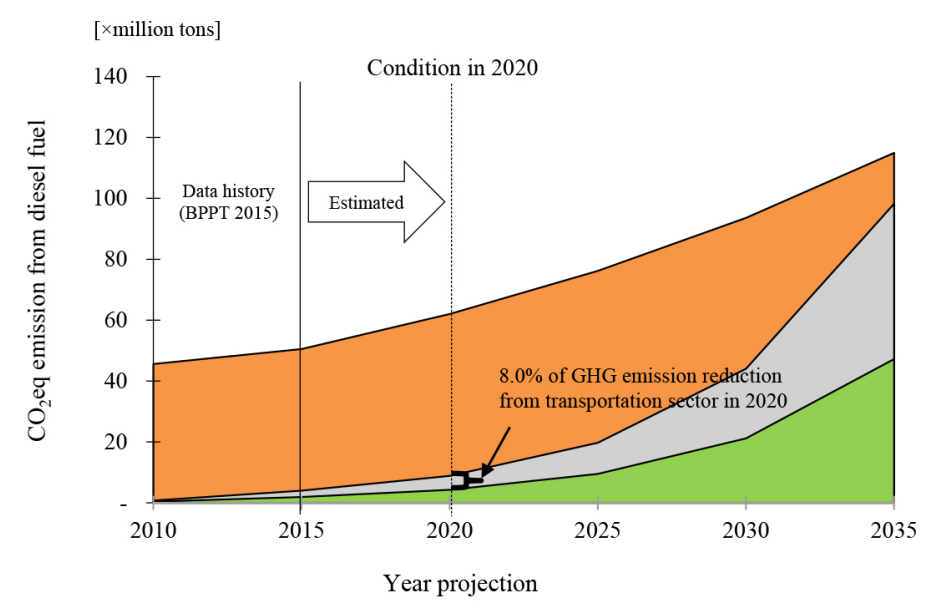

Total $\mathrm{CO}_{2}$ eq emission from diesel fossil fuel

$\mathrm{CO}_{2}$ eq emission from diesel fossil fuel replaced by biodiesel

$\mathrm{CO}_{2}$ eq emission from biodiesel utilization (based on the annual growth rate projection)

Fig. 8 Projection of $\mathrm{CO}_{2}$ eq emission from diesel fuel utilization

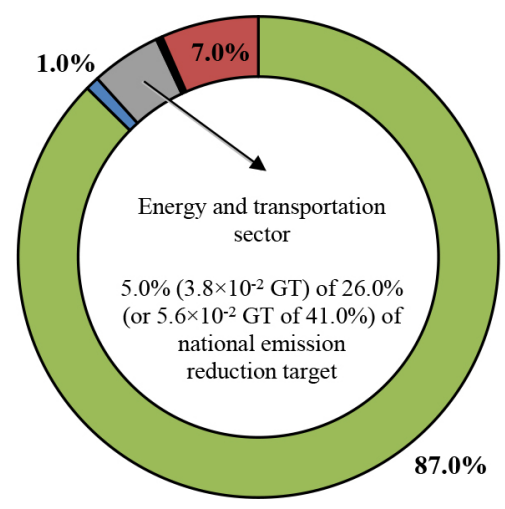

口Forestry \& Peatland

口Agriculture

口Energy \& Transport

- Industry

aWaste

Fig. 9 GHG emission reduction target in 2020 based on the Indonesian government policy 
ICE vehicle fueled by palm oil and microalgae based biodiesel approximately 69.06 and $58.93 \mathrm{gCO}_{2} \mathrm{eq} \cdot \mathrm{km}^{-1}$, respectively.

Based on lower tailpipe emission and high energy efficiency, EVs are well placed to benefit from these regulations. To deliver climate change benefits, net GHG savings need to be provided across the whole life cycle of the EVs and clean electricity supply. However, expanding the use of EVs as an alternative road transportation is also really depended on the power quality and electricity sources. Based on the report from IEA (2016a), the use of EVs result in net $\mathrm{CO}_{2}$ savings only if vehicles are coupled with the generated electricity to charge the battery has a carbon intensity below $700 \mathrm{gCO}_{2} \mathrm{eq} \cdot \mathrm{kWh}^{-1}$. This constraint is a challenge for countries such as Indonesia that are largely dependent on coal for power generation and has grid emission factor more than $757 \mathrm{gCO}_{2} \mathrm{eq} \cdot \mathrm{kWh}^{-1}$. As a comparison among selected ASEAN countries in Fig. 10, tail pipe $\mathrm{CO}_{2}$ emission values for Indonesia EVs was the highest. Indonesia, Malaysia, and Thailand have different energy mix in power generation. Based on 2016 data, the final tail pipe of EVs in Indonesia was lower than ICE vehicle fueled by Euro 2 standard-diesel, which was 128.69 and $143.66 \mathrm{gCO}_{2} \mathrm{eq} \cdot \mathrm{km}^{-1}$, respectively. This condition could change if in the immediate and future terms, the Indonesia government boosts EVs policy by utilizing more clean power from the national grid. The power generation in Indonesia is highly depended on the fossil fuel, especially coal-fired power plant which cover about $50 \%$ from total installed of domestic power generation (Sugiyono et al. 2016). We also found that for both biofuel and EVs policies contribute to relatively small in achieving GHG emission reduction target. Biofuel from microalgae showed lower $\mathrm{CO}_{2}$ eq emission than palm oil based since we cultivated in wastewater and utilized $\mathrm{CO}_{2}$ emission from flue gases (Articles in submission to the Journal for publication).

Tail pipe emission forecast for Indonesia scenario within the time frame 2015 until 2030 is shown in Fig. 11. Two straight lines on the top of Fig. 11 represents the tail pipes of EVs along the particular period. Both lines are increased over the years following the power generation mix target and forecast from 2015 to 2030. It was predicted that after 2021 the tail pipe emission from EVs would be higher than any other biofuel options in ICE vehicles.

As a comparison, the growth of the hybrid powertrain technologies of the Japanese vehicle fleet has increased in the last decade. The new roadmap for EVs released by the Japanese government in 2016 sets a new target of 1 million EVs in Japan by 2020 (IEA 2016a), replacing the Japanese 2010 Next Generation Vehicle Plan (NGVP) target of 15-20\% EV sales by 2020 (Maruyama 2014). The Electric Vehicle Supply Equipment (EVSE) deployment by 2020 may well align with the updated EVs deployment target. The condition would lead to an estimate exceeding 1 million EVSE outlets by 2020. Based on the 2016 comparison of tailpipe emission (Fig. 12), Japan road transportation system was ready for realizing electric vehicles. For $\mathrm{B} 100$, the tail pipe emission of palm oil based biodiesel in Indonesia is lower than Japan (69.00 compared to $70.60 \mathrm{gCO}-$ $\left.{ }_{2} \mathrm{eq} \cdot \mathrm{km}^{-1}\right)$. However, in contrary for B10 and B20, the tail pipe emission is less for Japan due to better in fuel economy (JC08) and ICE efficiency for the current situation and also the future target.

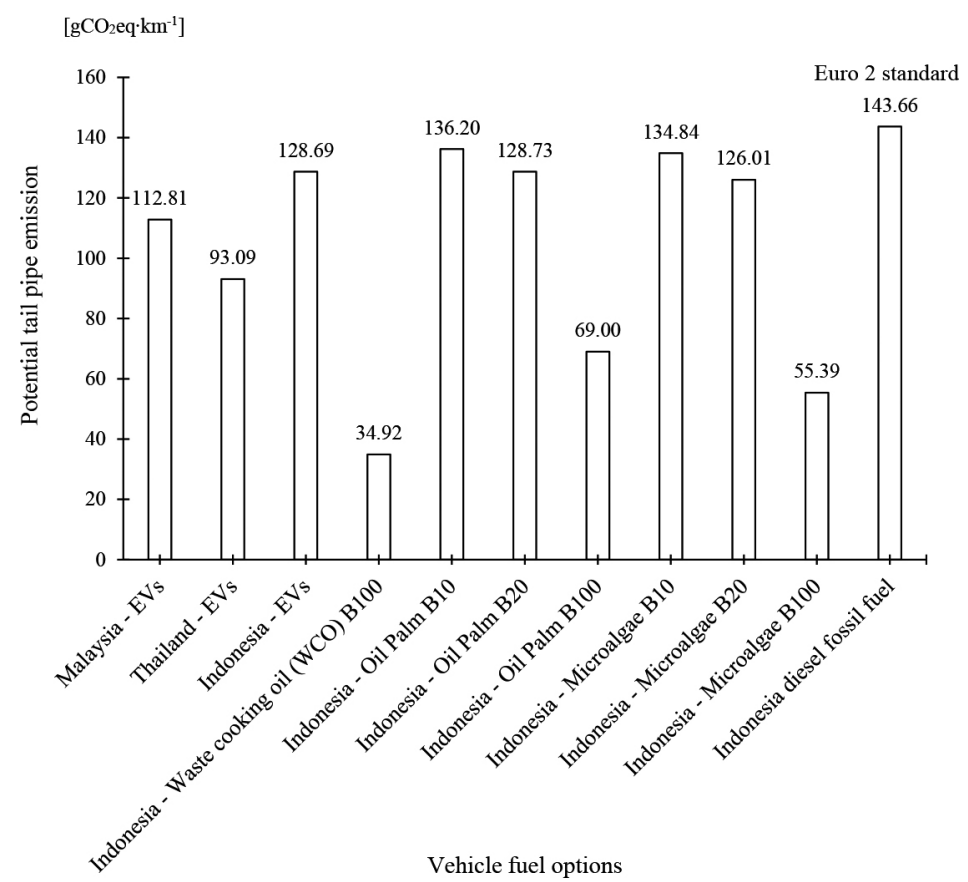

Fig. 10 Tail pipe $\mathrm{CO}_{2}$ eq emission for ASEAN scenario based on 2016 baseline data 


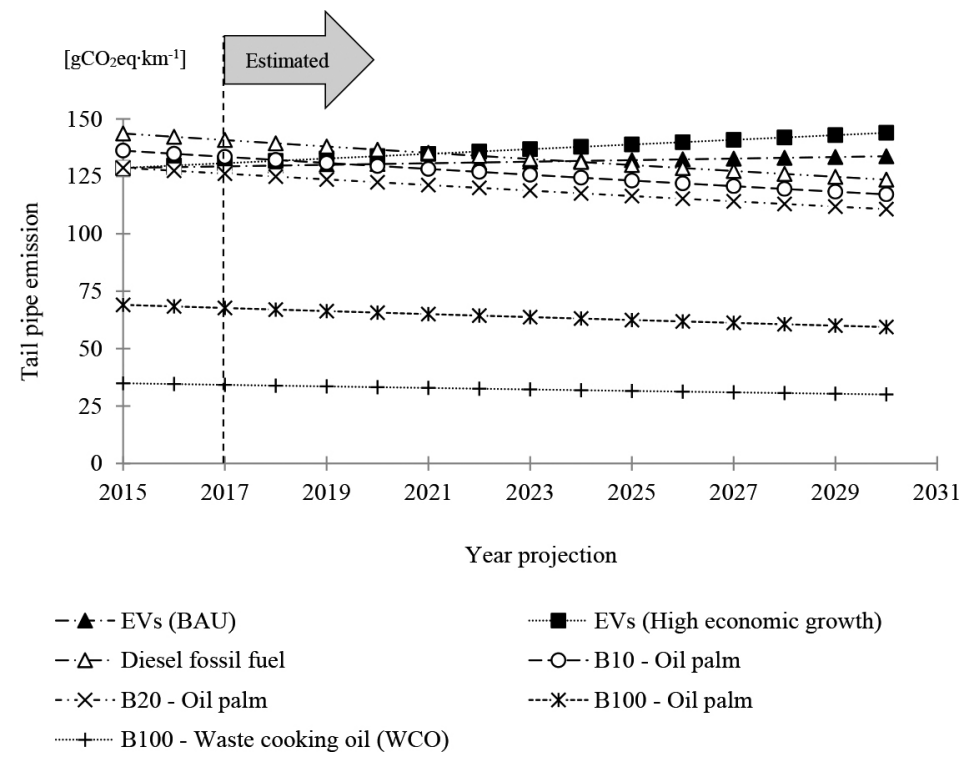

Fig. 11 Projected of tail pipe emission for Indonesia scenario (within 2015-2030 timeframe)

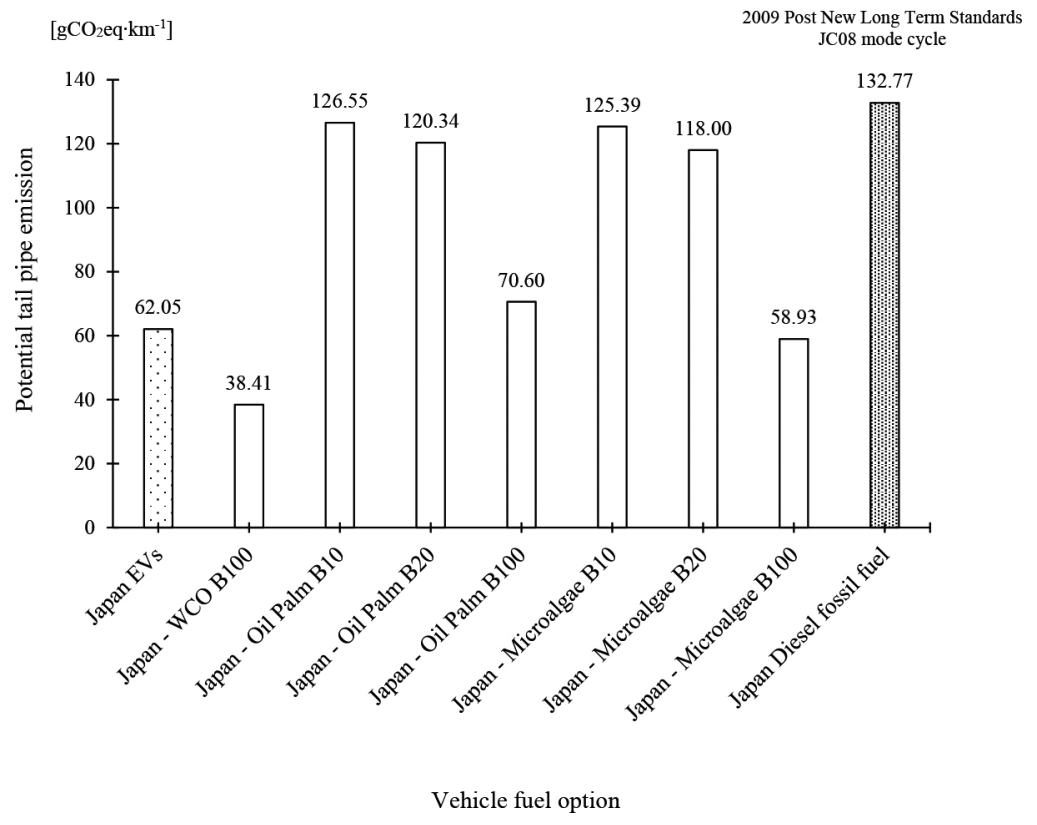

Fig. 12 Tail pipe $\mathrm{CO}_{2}$ eq emission for Japan scenario based on 2016 baseline data

Meanwhile, for Japan tail pipe emission scenario within the time frame 2015 until 2030 for several possible options is shown in Fig. 13. The EVs policy in Japan is supported by the NGVP, which was aiming at deploying 2 million standard chargers and 5,000 fast chargers across the country by 2020 (METI 2014). In 2015, around 6,160 fast charging outlets, 16,200 slow charging outlets, and 130,000 private charging outlets publicly available in Japan. In Japan, a partnership with a retailer for the installation of 500 fast chargers and 650 standard chargers at its stores, providing two-thirds of the funding (IEA 2016a).

However, Indonesia also has some on road test of EVs (Indrawanto 2013). National state-owned electricity company
(PLN) has launched a program for providing charging stations in many locations in several big cities in Indonesia. In 2009, it was launched EVs powertrain program (including electric buses), but it was failed due to some political constraints and technical issues.

Fig. 14 shows the forecast power grid emission factors up to 2030 for two countries, Indonesia and Japan. This result was estimated from the national power generation planning and national energy mix scenarios up to 2030. Based on the power generation mix situation in Japan, EVs policy is found suitable as a least carbon-intensive option. Meanwhile, based on the marginal scenario in Indonesia power sector, widespread adop- 


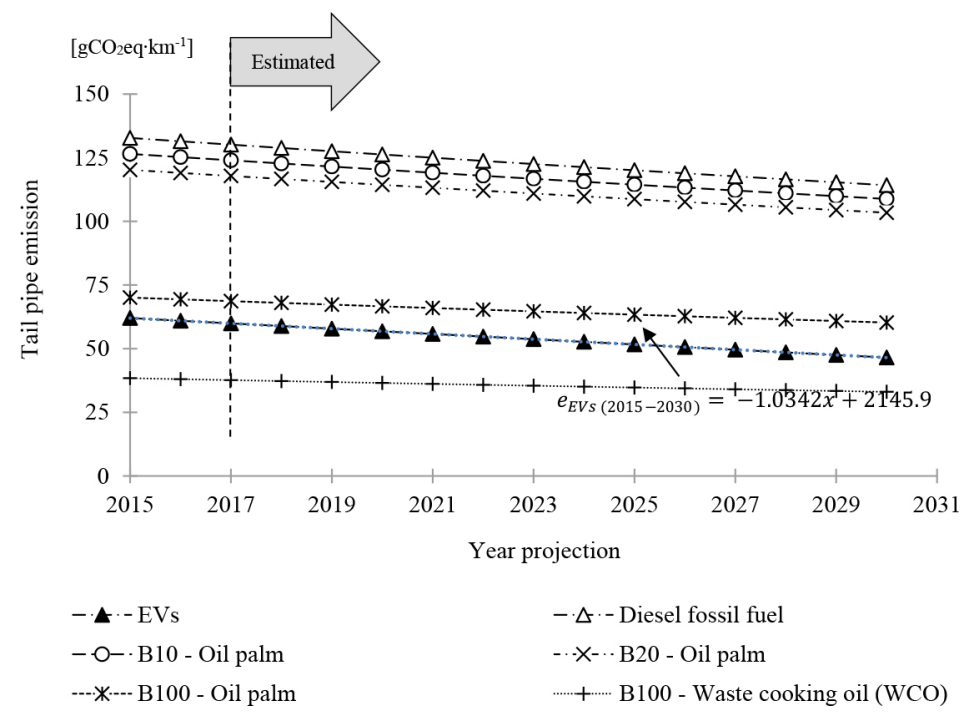

Fig. 13 Projected of tail pipe $\mathrm{CO}_{2}$ eq emission for Japan scenario (within 2015-2030 timeframe)

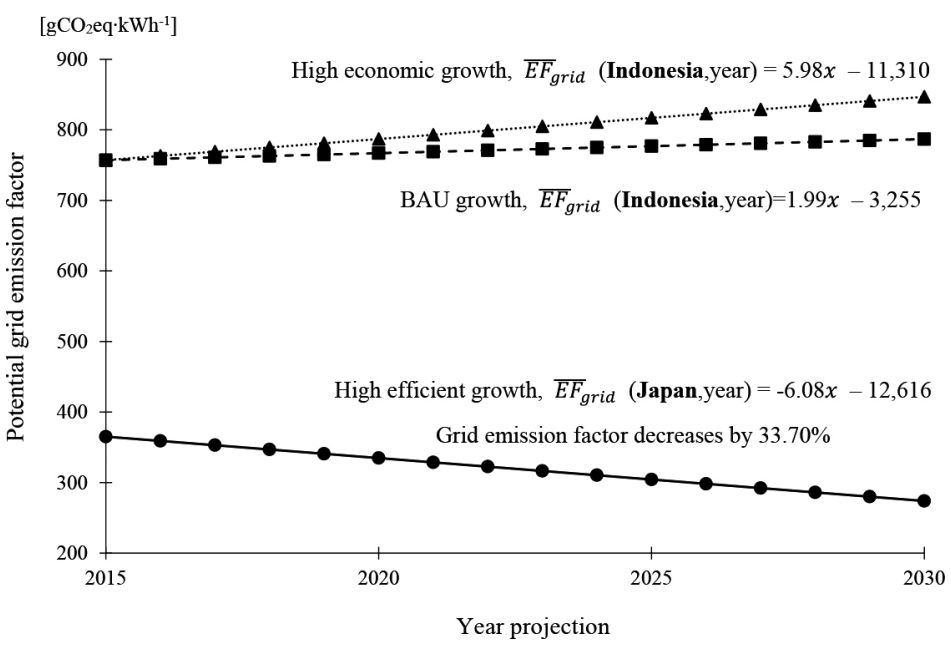

Fig. 14 Projected Japan and Indonesia tail pipe $\mathrm{CO}_{2}$ eq emission factor from power sector scenario within 2015-2030 timeframe

tion of EVs is found to be an unwise strategy if coal-fired power plant dominates the sources of electricity.

\section{LCA analysis by using a cradle to grave method for 2016} baseline

LCA results show that EVs potentially can contribute to lower tailpipe emission compared with current ICE vehicles fueled by fossil diesel or biodiesel in Japan. This was due to the readiness of low emission of power generation sector. The results as shown in Fig. 15 indicates that widespread adoption of EVs in Japan is a favorable strategy given by the existing and near-future electricity generation scenario, a contrary condition to Indonesia. The EVs in Indonesia could be contradictive with the proposed emission reduction target since coal-fired power plants are dominated in Indonesia power generation for today situation and future.
If most of electricity supply is generated from coal-fired power stations, then the use of EVs has a greater impact on the environment than the utilization of a vehicle with a conventional ICE fueled by fossil diesel for most of the environmental impact categories considered. However, if the battery of the EVs is charged with electricity from a renewable source, such as hydro or wind power, then the EVs might have a great positive impact to the environment than a vehicle running on fossil fuels.

A comparison of environmental impacts for both options needs to be based on a life cycle perspective. However, biodiesel based palm oil offers relatively lower GHG emission reduction potential and possibly faces limited resources and farm lands. Rather than focus on liquid fuels, electricity based biomass and biogas power generation would be a good option with regard to bio-resources and waste to energy utilization. 
$\left[\mathrm{gCO}_{2} \mathrm{eq} \cdot \mathrm{km}^{-1}\right]$

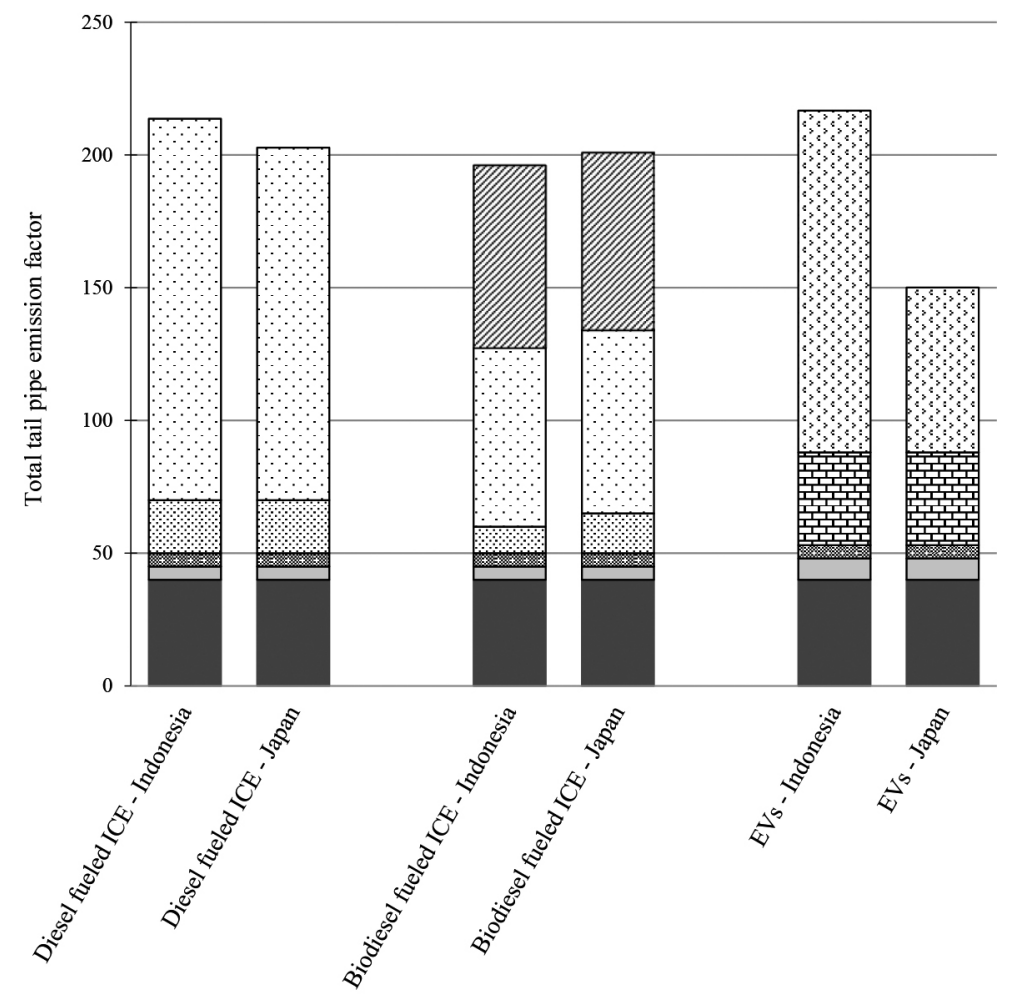

$\begin{array}{ll}\square \text { B10 emission } & \square \text { Tailpipe emissions } \\ \text { ⿴囗大ol suel supply } & \square \text { Electricity supply } \\ \text { ⿴囗十) Battery } & \square \text { Maintenance } \\ \square \text { Vehicle end-of life/ Disposal } & \square \text { Vehicle production }\end{array}$

Fig. 15 LCA cradle to grave scenario of tail pipe for Japan and Indonesia based on baseline 2016 data

\section{Policy recommendation}

At least 9.0 GW power generation capacity or $80.0 \mathrm{TWh}$ electricity produced from coal-fired power plant should be replaced by low GHG intensity sources of power generation such as biomass based power plant with emission factor around $22.33 \mathrm{gCO}_{2}$ eq $\mathrm{kWh}^{-1}$ to achieve relatively the same emission reduction ratio as in Japan for 2016. This strategy will require more clean power generation share to accommodate EVs for the green mobility policy in the future. The Indonesia government put $23.0 \%$ share of new and renewable in the national energy mix by 2025 . However, it seems very difficult to achieve since current national renewable energy development growth only $0.36 \%$.

To achieve a significant reduction in $\mathrm{CO}_{2}$ emissions for automobiles, the integrated approach initiative must be implemented to increase vehicle fuel economy and alternative energy sources. Various measures are necessary to promote the widespread use of the next-generation vehicles, especially for Indonesia. The current energy mix policy in Indonesia seems to run out of the initial path, which should reduce the GHG emission. Some possible action plans and policy recommendation that might appropriate to be proposed for future green mobility in Indonesia, are given below:

1. The government needs stringent implementation on fuel economy and tailpipe $\mathrm{CO}_{2}$ emission standards and regulation for old and new vehicles.

2. Technology improvement for ICE with higher fuel efficiency standard.

3. Decarbonize power sector and increase the share of renewables to facilitate penetration of the use of EVs.

4. Encourage more green vehicles to run on the road by providing incentives to end user, choosing the most efficient options.

5. Increase transportation system efficiency by changing travel behavior, and implement an appropriate Transportation Demand Management (TDM) (Maruyama 2012).

6. Policy option on shifting urban mobility to public transportation, which has the high economic benefit and fuel-saving. Furthermore, this policy is among the best of cost-effectiveness to reduce emission by improving the passenger transport capacity and mitigate traffic congestion. 


\section{Conclusions}

From the previous results and discussion, we can conclude several points, as below:

1. Japan has a clear roadmap and policy in reducing emissions for automobile than Indonesia. Especially for EVs, a low emission factor of the electricity grid gives the advantage in promoting future green mobility.

2. Biodiesel utilization is not enough to achieve emission reduction for Indonesia road transportation sector (only $8.00 \%$ in 2020). EVs might potentially support lowering the GHG emission on road transportation, but since fossil fuels dominate the power generation sector in Indonesia, it gives the negative impact to the automobile emission reduction strategies in Indonesia.

There is no a simple answer to achieve emission reduction target for road transportation. In other words, it does not mean that switching from fossil fueled ICE to EVs necessarily reduces the impact to the environment even in the long term. A comprehensive review of current and future policy and action plan for GHG reduction in road transportation is necessary to find the best strategy for future automobile sectors, especially in Indonesia.

\section{Acknowledgement}

This work was supported by the Indonesia scholarship program for research and innovation in science and technologies (RISET-PRO) World Bank Loan No. 8245-ID and a visiting scholars program at Institute of Energy Economic, Japan (IEEJ) 2015.

\section{References}

Argonne National Laboratory (2017) The Greenhouse gases, Regulated Emissions, and Energy use in Transportation Model, <https:// greet.es.anl.gov/index.php.>, browsed on January, 2017.

Asia Pacific Energy Research Centre (APERC) (2016a) APEC Energy Demand and Supply Outlook 6th Edition, <http://aperc.ieej.or.jp/ file/2016/5/10/APEC_Outlook6th_VolumeI.pdf $>$, browsed on May, 2016.

Asia Pacific Energy Research Centre (APERC) (2016b) Study on Policies to Lower Oil Demand in the Transport Sector in the APEC Region, <http://aperc.ieej.or.jp/file/2016/9/8/IEEJ_revised_ 06272016_APEC_Oil_Demand_Restraint_Measures_in_Transport. pdf $>$, browsed on September, 2016.

Association of Indonesia Automotive Industries (GAIKINDO) (2017) Interactive Data \& Visualization, <http://www.gaikindo.or.id/ data-interaktif/>, browsed on June, 2017.

European Environment Agency (EEA) (2016) Explaining road transport emissions. A non-technical guide, <http://www.eea. europa.eu/publications/explaining-road-transport-emissions $>$, browsed on January, 2016.
European Road Transport Research Advisory Council (ERTRAC) (2016) Future Light and Heavy Duty ICE Powertrain Technologies. ERTRAC Working Group: Energy and Environment, <http://www. ertrac.org/uploads/documentsearch/id42/2016-06-09_Future\%20 ICE_Powertrain_Technologies_final.pdf>, browsed on June, 2016.

Fairhurst, T. and McL. David (2009) Sustainable Oil Palm Development on Degraded Land in Kalimantan, World Wildlife Fund (WWF), $<$ http://tropcropconsult.com/downloads_files/Fairhurst2009.pdf>, browsed on March, 2016.

FIA Foundation (2016) Fuel Economy State of the World. GFEI. $<$ https://sustainabledevelopment.un.org/content/documents/ commitments/2505_7519_commitment_gfei-state-of-the-worldreport-2016.pdf>, browsed on December, 2016.

GFEI (2017) Global Fuel Economy Initiative, <http://www. globalfueleconomy.org/>, browsed on January, 2016.

Gingold, B., A. Rosenbarger, Y. I. K. D. Muliastra, F. Stolle, I. M. Sudana, M. D. M. Manessa, A. Murdimanto, S. B. Tiangga, C. C. Madusari and P. Douard (2012) How to Identify Degraded Land for Sustainable Palm Oil in Indonesia. WORKING PAPER, Washington D.C.: WRI / SEKALA, <http://data.wri.org/POTICO/ English_how_to_identify_degraded_land_for_sustainable_palm _ oil_in_indonesia.pdf>, browsed on April, 2016.

Indonesian Police Office (2016) Motor vehicle registration and license plate number in Indonesia, <http://korlantas.polri.go.id/stnk/>, browsed on December, 2016.

Indrawanto (2013) Toward the Establishment of Indonesian Automotive Research and Development Institute (INARD). 2nd Asian Automotive Institute Summit. Denpasar - Bali, <http://www.jari. jp/Portals/0/resource/pdf/AAI\%20Summit/H25/1.\%20INARDO. pdf $>$, browsed on January, 2016.

Institute for Global Environmental Studies (IGES) (2017) List of Grid Emission Factor. Excell file, <https://pub.iges.or.jp/pub/list-gridemission-factor $>$, browsed on January, 2017.

International Energy Agency (IEA) (2016a) Global EV Outlook 2016, Beyond one million electric cars. OECD/IEA, <https://www.iea. org/publications/freepublications/publication/Global_EV_ Outlook_2016.pdf>, browsed on December, 2016.

International Energy Agency (IEA) (2016b) Mobility Model. database and simulation model, IEA.

Japan Automobile Manufacturers Association Inc. (JAMA) (2016) Motor Vehicle Statistics of Japan, <http://www.jama-english.jp/ publications/MVS2016.pdf>, browsed on September, 2016.

Junoasmono, T. (2015) Indonesia Road Sector Development. Tokyo, October 27-28, <https://www.road.or.jp/international/pdf/31_1. pdf $>$, browsed on October, 2016.

Kawakami, Y. (2016) Projecting average stock fuel economy for minisized passenger vehicles. Tokyo: IEEJ, <https:/eneken.ieej.or.jp/ data/6660.pdf $>$, browsed on May, 2016.

Maruyama, H. (2012) Rational Approach for CO2 Reduction in Transportation Sector. Tokyo: Japan Automobile Manufacturers Association, Inc., March 29, <http://eneken.ieej.or.jp/data/4312. pdf $>$, browsed on March, 2016.

Maruyama, T. (2014) Japan's Initiatives for the diffusion of NextGeneration Vehicles, <http://www.cev-pc.or.jp/english/events/ okinawa2014/02.pdf>, browsed on February, 2016.

Ministry of Economy, Trade and Industry (METI) (2014) Government Initiative for Promoting Next Generation Vehicles, 20th Automotive Dialogue Beijing, China 22-25 April 2014, <http:// mddb.apec.org/Documents/2014/AD/AD1/14_ad1_025.pdf>, browsed on December, 2016. 
Ministry of Economy, Trade and Industry (METI) (2015) Long-term Energy Supply and Demand Outlook, <http://www.meti.go.jp/ english/press/2015/pdf/0716_01a.pdf>, browsed on January 2016.

NISSAN (2017) Nissan Leaf UK Brochure. <https://www.nissan-cdn. net/content/dam/Nissan/gb/brochures/Nissan_Leaf_UK.pdf $>$, browsed on January, 2017.

Onat, N. C., K. Murat and O. Tatari (2015) Conventional, hybrid, plugin hybrid or electric vehicles? State-based comparative carbon and energy footprint analysis in the United States, Applied Energy, 150: $36-49$.

Perotti, R. and M. F. Coviello (2015) Governance of Strategic Minerals in Latin America: the Case of Lithium. Santiago: Economic Commission for Latin America and the Caribbean (ECLAC), $<$ http://repositorio.cepal.org/bitstream/handle/11362/38961/ S1500861_en.pdf $>$, browsed on September, 2015.

Presidential Decree No 61 (2011) The national action plan on greenhouse gas emission reduction. Jakarta: President of Republic of Indonesia, September 20, 2011.

Presidential Decree No 71 (2011) The operation of national greenhouse gas inventory. Jakarta: President of Republic of Indonesia, October 5, 2011.

Safrudin, A. (2016a) Carbon Tax: A proposal for co-benefit low carbon emission, and energy efficiency in transportation sub-sector in Indonesia, Jakarta, KPBB.

Safrudin, A., et al. (2016b) Phase 1 of SSFA: Improving Fuel Quality and Fuel Economy in Indonesia, Cost-benefit analysis fuels economy, Final Report, Jakarta, The Ministry of Environment Republic of Indonesia.

Smit, H. H., E. Meijaard, C. van der Laan, S. Mantel, A. Budiman and P. Verweij (2013) Breaking the Link between Environmental Degradation and Oil Palm Expansion: A Method for Enabling Sustainable Oil Palm Expansion, PLoS ONE, 8(9), e68610.

Sugiyono, A., et al. (2016) Indonesia energy outlook 2016: Energy development in supporting green industry. Jakarta: Centre for Energy Technology and Chemical Industry, BPPT, <https://bppt. go.id/unduh/outlook-energi $>$, browsed on January, 2017.

Swiss Resource Capital AG (SRC) (2016) Lithium Report 2016, $<$ https://www.resource-capital.ch/fileadmin/reports/2016/kw38/ en_Lithium_ES.pdf $>$, browsed on August, 2016.
The Ministry of Energy and Mineral Resources (MEMR) (2015) Regulation No. 12 about supply, utilization, and the marketing of biofuels as other fuels,

$<$ http://jdih.esdm.go.id/peraturan/Permen\%20ESDM\%2012\%20 Thn\%202015.pdf $>$, browsed on January, 2016.

The Ministry of Energy and Mineral Resources (MEMR) (2017) Electricity Business Plan of National Electricity Company PT. PLN (Persero) year 2017-2026. Jakarta: The Ministry of Energy and Mineral Resources, Indonesia, $<$ http://www.djk.esdm.go.id/index. php/rencana-ketenagalistrikan/ruptl-pln>, browsed on August, 2017.

The National Development Planning Agency of Indonesia (BAPPENAS) (2016) Sustainable Transportation Policy in Indonesia, <http:// www.isdb-am41.org/wp-content/uploads/2016/06/5-BAPPENASSustainable-Transport-Policy_IDB_150516-1.pdf $>$, browsed on August, 2016.

United Nations of Framework Convention on Climate Change (UNFCCC) (2008) Decisions adopted by the Conference of the Parties. Report of the Conference of the Parties on its thirteenth session, held in Bali from 3 to 15 December 2007, Denpasar, Bali: UNFCCC, < https://unfecc.int/resource/docs/2007/cop13/ eng/06a01.pdf $>$, browsed on December, 2015.

US Department of Energy (2017) The official U.S. government source for fuel economy information, <https://www.fueleconomy.gov/>, browsed on February, 2017.

World Energy Council (WEC) (2016) World Energy Perspectives E-Mobility 2016,

$<$ https://www.worldenergy.org/wp-content/uploads/2016/06/ E-Mobility-Closing-the-emissions-gap_full-report_FINAL_2016. 06.20.pdf $>$, browsed on January, 2017.

Wright, T. and A. Rahmanulloh (2017) Indonesia Biofuels Annual. GAIN Report, Jakarta: USDA Foreign Agricultural Service, $<$ https://gain.fas.usda.gov/Recent\%20GAIN\%20Publications/ Biofuels\%20Annual_Jakarta_Indonesia_7-28-2016.pdf $>$, browsed on August, 2016.

Received April 17, 2017

Accepted August 22, 2017

Agro-informatics \& Technology 